\title{
THE CONCH SHELL
}

\section{MARISA MADIERI}

\section{(Trans. Anne Milano Appel) ${ }^{1}$}

The manutara have returned. They arrive from the sea each year, in great flocks, indecipherable heralds of the unknown. At first a dark blur appears on the horizon, seemingly motionless as it swells imperceptibly. Then, all of a sudden, the blur advances, a swift cloud that spreads out, expands, looms over us; the sky is pierced by a thousand arrows. With shrill cries the birds begin wheeling over the island in confusion, not daring to land, still incredulous at having reached their destination. Most of them choose the rocky cliffs of Motu Nui and Motu Iti for nesting.

Their arrival marks the timing of our ceremonies and denotes the rhythm of the seasons, the alternation of periods of rain with dryer, cooler times. We await them anxiously, as though they were a divine gift, almost fearful that the miracle of their appearance might be denied us by the ire of the gods. One of the most important feasts of the year is dedicated to their return.

Where do they come from? As a young man I observed them with interest and curiosity, but did not ask myself these questions. The island was enough for me. It provided me with everything I needed, pure water in the craters of the volcanoes, the shade of the wooded slopes, fruits of the earth, fish of the sea.

My days were full and industrious. In the prolonged span of my life I have grown crops, fished, sailed, crafted huts and slender pirogues. Following in my father's footsteps, I became a skilled sculptor and woodcarver. It was he who taught me to carve statues of the ancestral spirits from the woody trunk of the toromiro. The finest moments of my days have been spent working undisturbed behind the hut where I placed a comfortable stone seat. I have always let my thoughts flow along while keeping my hands occupied. Before me lay a broad expanse of dark grass, beyond that,

1 The original version of the short story "La conchiglia" was previously published in Verde acqua, La radura e altri racconti by Marisa Madieri (Turin: Einaudi, 1987, 1992, 1998, 2006). It appears here for the first time in English translation with permission; all rights reserved, Anne Milano Appel, (c) 2011. 
the foamy ocean. In the distance I could hear the voices of the younger children, Naipuni's calls, the incessant chattering of the neighbours. I portrayed the spirits as scrawny, skeletal, their skin withered over their protruding ribs, their backs curved, their hollow bellies consumed by primeval hunger. Their eyes however I carved round, immense, wide open on the mystery of afterward and beyond.

Like all the members of the village, I have spent a great deal of time in the pit of the volcano sculpting the moai of my tribe, which have been erected on the sacred platform.

Now I am old and I come more and more often to this beach, on the bay of Anakena. It is one of the few with white sand, a miracle of shining whiteness among the dark rocky cliffs that encircle the island. It is not very far from my dwelling place. I leave when the sun is still low and arrive before it is high in the sky.

The legends of my people, handed down from father to son or transcribed on long wooden tablets with signs that only a few can read, say that here, many years ago, our forefathers from Hiva landed, under the command of Hotu Matua. The stories tell of far-off lands, of a people forced to leave there, to seek out new terrains in order to survive. They speak of hope, of courage, of fear of the unknown, of the pain of separation.

Hotu Matua was the son of a king. He lived on a prosperous, happy, populous island. One day he decided that it was time for his group, by now too numerous, to migrate. They began meticulous preparations for their departure. Large outrigger canoes, capable of holding even entire families, were loaded with seeds, plants, animals, water and food supplies. They did not neglect to take bone models of all sorts of tools, to be copied upon arrival. When everything was ready, the family groups set out in the direction of the rising sun, just as other predecessors of ours had done. Only in that direction could uncharted territories lie. They sailed for days and nights amid storms, dead calms, waves as high as walls, studying the horizon in search of a hospitable coast. The moon grew full and then began to wane. Soon enough confidence turned to despair. Nothing but water lay before them. The angry gods had forgotten them.

Many did not survive and died of starvation, but in the end the few survivors saw this green land rising from the sea like an apparition. After locating a convenient inlet along the high, impenetrable coast, they chose this beach for their landing.

Many ariki followed from that distant day until the present. Though they lived in the past, the memory of their names and their exploits is our only link to other men, our only anchor in this sea of solitude. 
On the throne at the time of my birth was Taaroi, the thirty-seventh ruler after Hotu Matua. A great king, capable of commanding obedience through the force of reason and wisdom. No one would have dared to disregard his commands, violate his laws. He was a just man, gentle, yet he could be uncompromising with violent individuals or plotters and schemers.

He was also provident. Seeing that the island's population was slowly increasing and realizing that further migrations were not possible, to avoid future disputes he decided to divide the territory into segments, starting from the center out toward the coast, assigning one of these segments to each village. In this way everyone would know where they could clear away trees without creating antagonisms, raising their farm animals and growing their crops in peace. And so it was for many seasons.

He was succeeded by the current Ariki Hana, who by now has been on the throne since time immemorial. Today he is a lethargic, absent old man, nearly blind, unable even to die. He no longer speaks to anyone. He has not been a wicked ruler, but indolent and unfocused, a man who loves comfort and food. His corpulent, flabby body and feminine forms, the swollen features of his face, in which his eyes seem like two narrow slits, suggest the idea of an almost vegetal inertia.

King Hana has always had a horror of decisions made too hastily and of any act meant to institute definitive changes, maintaining that innovations, inevitable even apart from man's will, can only worsen the current situation. If someone requested permission to build a new path to connect two villages, or offered him the opportunity to create another place of worship, he always gave the same response: maybe tomorrow. And so, seizing upon the fact that 'maybe' is not a refusal, everyone acted as they saw fit.

And for better or for worse, there was no lack of changes: sometimes explosive, and sometimes slow, almost imperceptible. Our community grew and settlements proliferated along the coasts. In each of them new ahu were built to hold new moai. And this was a good thing.

But the atmosphere of harmony that had reigned among the groups at one time was strained. Mutual trust vanished, nowadays suspicion is the rule. Increasingly, in fact, the division of land established by Taaroi is no longer respected, and thefts and incursions into other men's property occur frequently. And this is a bad thing.

I have travelled across my small country many times on foot. I know its unyielding cliffs, its black volcanoes, its rare harbours, its villages watched over by gigantic moai with eyes of coral. Though not large, at one time it seemed to me to be sufficient and perfect. Today it is no longer 
enough for me. The haven of one time has become a prison.

From the white beach of Anakena I look to the west and retrace in my imagination the impossible voyage of our forefathers. Who knows if our legends speak the truth, if we really descended from men who lived in other lands or if we were born of the Bird Man, whom we celebrate in our rites. Perhaps at one time we were all divine birds, who were then punished for some obscure sin and deprived of the possibility of inhabiting the infinite celestial vault.

The island is our mother and our curse. Many times we sent explorers out in all directions and the few who returned reported that there was nothing there except the briny ocean. Season after season, generation after generation, our horizon has been empty.

Sometimes I climb to the top of the highest volcano and, if the sky is clear, I study that line that joins the two blue infinities that surround me; it feels unreachable, yet close enough to touch, almost as though it were a band wound around my forehead. I feel its cold contact on my skin and it takes my breath away. I myself would like to become that line to unveil the mystery of what lies beyond.

Is there an end to the sea? Perhaps the manutara know the answer. The birds, after raising their brood, take off each year toward unknown destinations. Some maintain that they do not go very far, but settle down to feed in the vast pastures of the sea; others believe that they plunge into the waves, to become fish, later transforming themselves into winged creatures again; only a few think they reach other lands. I myself fear that this ring of water is the only reality and our only destiny.

The village where I live is found on the bay of Tongariki, on the southern side of the island. It was established by Hotu Matua and is still today the place where his successors reside. It stands not far from the volcano Rano Raraku, from whose slopes the stone needed to construct the ancestral statues, our guardians, was obtained.

The huts are clustered at the center of a broad flat plain, a short distance from the shore. But a huge ceremonial platform separates us from the beach: an extensive stone ahu, which our ancestors began to construct as soon as they landed, to give thanks to the merciful gods. On this pedestal stand the moai of our tribe. They have their backs to the sea and their towering presence seems to defend us against its cruel immensity. Their eyes with the obsidian irises, wide-open, gazing fixedly at the village, emanate the mana necessary to our lives, and the more numerous they become, the more effectively evil is kept at bay.

At times I wonder if that imposing stance, almost one of disdain 
toward the infinite ocean, also served the purpose of sparing our ancestors' images the unbearable sight of nothingness.

Nights on my island are stirring, bottomless. Darkness, which arrives suddenly and spills over things like a waterfall, engulfing them, shrouds the unfathomable mystery of our lives in a star-studded silence. The voices of men and animals are quiet, children sleep, the evening fires stop crackling, all that remains are the words of the wind - rolling down from the tops of the volcanoes over the vast plains - beneath those of the sea that roars and breaks incessantly against the high rocky cliffs.

East of Mount Poike, far from any village, lies a special place, solitary and tranquil, where there is a smooth stone called "the rock from which to observe the stars". Here our wise men study the mysterious movements of the celestial bodies and the constellations and try to conjecture their influence on our lives.

I have been fascinated by this place since I was a boy. If I had something weighing on my heart, a decision to make or even a private cause for happiness, in the evening I would go in secret to the stone. I waited for darkness lying on its surface that still held the day's warmth, and I was alone and naked in the immensity of the sky, sinking into staggering obliteration.

The star-gazing rock is indissolubly linked to my life, or better yet to that part of my life that Naipuni did not carry off with her. So much time has passed since her death, that I can barely recall her features. It is as though her face has dissolved into things, commending herself to them. Sometimes a gust of warm wind suddenly brings me the memory of the scent of her skin, the flight of a bird reminds me of her youthful grace, the rain that bathes me is the light caress of her fingers.

Naipuni was my wife. I knew her since childhood. We played together, with joyful abandon, among the other children in the village. In noisy droves we chased the chickens in the pens for the fun of seeing them cackle, we climbed palm trees to see who was more skilful, we often plunged into the cold, clear waters of a bay sheltered from the wind and churning waves that almost always whip the coast. We swam happily until our lips turned blue and the skin of our fingertips puckered.

Naipuni was a bold little girl and she never cried, not even when she tumbled on the ground and scraped a knee, causing it to bleed. She managed to hold back the tears that glistened on her eyelashes. Only once did I see her burst into sobs, during a scuffle with a boy who was quite a bit older and stronger than her. They were fighting over a staff that someone had lost, which had a finely carved two-faced head on one end. Infuriated, 
since she maintained that the staff was hers for having personally found it in the grass, she bit her contender's arm before being overpowered by him. The boy in turn brutally shoved her, making her fall to the ground. Then he ran off, taking the staff from her.

When I realized what was happening I hurried over to help the victim of that outrage. Naipuni's cheeks were caked with dirt and lined with tears. I helped her get up and, gently grasping her slender wrist, accompanied her to the shore to wash her face. I picked up a conch shell, one of those white ones with the rose-pink inner lining that the rolling waves deposit on the sand, and offered it to her, almost as though to compensate her for what had been unjustly taken from her. She looked at me, confused and grateful, her eyes shining, washed by her tears. She took the shell and immediately held it to her ear, absorbed in listening to the mysterious music imprisoned within it.

Many seasons passed. Our encounters became more rare. The time for playing games was succeeded by that of duty. My father had begun teaching me the skill of building huts and pirogues, besides introducing me to the secrets of sculpture and carving. And since I was the oldest of the children, my mother needed me to tend to the poultry and grow the potatoes, yams and taros. The young plants had to be watched over constantly, and stone walls had to be built around them to protect them from violent winds and the sun's scorching heat.

One day, when I was already an adolescent, I went to the top of the Rano Aroi volcano to gather some totora reeds that grow in the waters found in the crater. My father would lash them together to form a simple, sturdy fishing boat.

Naipuni was there, along with her older brothers who had gone up there for the same reason I had. She was kneeling at the edge of the small lake gazing at her reflection, her long black hair trailing the surface. She had placed a red flower behind her ear as she had seen the older girls do. After a while she plunged her hands into the water and cupping it, brought it to her lips to quench her thirst. In that position that was almost one of prayer, her eyes met mine. She lowered her eyes, furtively removed the flower from her hair, and retreated, embarrassed. She quickly caught up with her brothers who were already starting down the slope, their backs laden with reeds. For a moment I saw her outlined against a sky of innocent blue-slender, dark, mine.

That evening I felt the need to go to the star-gazing rock to be alone and sort out the turmoil of my thoughts. My heart was an empty vessel in the center of my chest, my breathing rapid and almost imperceptible. I felt 
suspended in air like a manutara gliding on the wind. I realized that my destiny was sealed.

I returned to my hut barely able to find the path in the moonless darkness, as thousands of the night's distant eyes caressed and transfixed me with longing.

If the ring of water that encircles my island is a vast, bitter enigma, no less great is the mystery of the countless caves and tunnels that bore through the rock faces of its cliffs on all sides, at times opening onto the immensity of the ocean. The walls of many caves are decorated with figures carved or painted on the rock. It is Makemake, the creator god, king of the living and the dead, who is most often depicted, with his broad face and wide vacant stare, forbidding lord of the shadows that surround him.

It is here that the spirits of the dead reside. But it is not uncommon to find some living person-either out of fear or to expiate a sin or due to dark despondency-who has chosen the bowels of the earth as his dwelling place, finding the sun's allure abhorrent and the company of other men repulsive.

One of the most beautiful and unsettling caverns is that of Kalenga, which has two openings that look out on the ocean.

I went there often as a boy. I would sit in the entry of the main opening, a gap of dazzling light cut into the damp darkness of the interior, and watch the clouds scudding swiftly along the celestial vault. Clouds are a constant and familiar presence in our lives. Like the birds, they inhabit the lofty, unreachable sky. They appear suddenly on the horizon, conjured up from the void and driven by the wind that blows supreme. They thicken rapidly, obscuring the sun, they swell and clash like fierce warriors and then just as quickly break apart and shred to pieces, swept away by the force that generated them. Often their passage brings a brief, violent downpour or saturates the air with thousands of intangible droplets.

From that height I sometimes liked to pitch stones into the sea, far far away. I watched them as they moved through the air, straight and swift at first, then more slowly and inexorably doomed to fall. Their brief course and the spray of white foam they caused upon hitting the water's surface, almost like a last paroxysm of rebellion before being irrevocably swallowed up, reminded me of the brevity of a man's life and his reluctance to die.

When old Mauroa went to live in the cave of Kalenga with her chickens, I stopped going there. That wrinkled, bony creature inspired awe and fear in me, with her sagging breasts, her disturbed, piercing eyes and that long gray hair that fell half-way down her back, stringy and unkempt. 
Mauroa had lost her husband and adolescent children during a storm. The rapacious sea had closed over them and on her now useless life.

She was kind-hearted despite being hardened in her ways as a result of her adversities. She loved children, who were not put off by her appearance and approached her without fear, even after her voluntary exile from the community. She was always ready to cuddle them and share with them whatever meagre things she possessed.

Mauroa was extraordinarily skilled at body tattooing and face painting, a talent that became apparent during the frequent competitions that take place among the clans. Many began having their faces painted by her for the ceremonies, compensating her with gifts if the result satisfied them. In this way she was able to achieve a modest degree of comfort in the final years of her life, as well as the acknowledged role of a wise person, respected by all. But no one could ever convince her to leave the cave and return to the village to live.

My people are a cheerful group, they love feasts. Any occasion is a good time to gather together, prepare banquets, play music and dance in the evening around the fires on the ocean's shore. Some celebrations-marriages, births or a child's first haircut—only apply to the members of a certain family group, others, more solemn, bring the whole village together, but the most important festivity is the one that celebrates the return of the manutara. The entire population of the island partakes in it, after carefully making preparations to show off the best musicians and dancers, the richest and most imaginative costumes and ornaments. The day is a triumphal display of bird feathers, necklaces of bone and shell, straw hats, and elegant face and body painting.

The festivities begin in the early morning. Everyone gathers on the sea cliffs of Orongo, adjacent to the volcano Rano Kao, before which lie the two small islands of Motu Nui and Motu Iti. Our Ariki arrives there surrounded by his warriors and preceded by the high priest, who immediately sacrifices some cockerels to the gods to propitiate them. When the sun reaches its zenith in the sky, the most exciting part of the festival begins, a competition to snatch an egg laid by a bird on a rocky cliff, defying the strong currents and sharp rocks, and delivering it intact into the hands of our Ariki, who waits at the top of the rugged cliff, imperturbable, as befits a king of divine lineage.

A mantle of soft tapa, the cloth that our women make from the bark of trees, is then awarded to the winner and great honours are bestowed on him until the next race, which will crown a new champion.

The merriest part of the feast starts in the afternoon, with tourna- 
ments, singing and contests in the skills of body painting and rope weaving. During these competitions refrains and proverbs are recited in chorus, and humorous stories are told.

In the evening fires are lit and we all gather for a sumptuous banquet, which features the most generous gifts of land and sea-coconuts, sweet potatoes, yams, chicken, fish of every kind, and glorious vividly coloured lobsters. Finally singing and dancing sweeten the night, continuing until the first light of dawn.

At one such feast I found the courage for the first time to approach Naipuni and declare my love for her.

The banquet had ended long ago and the moon was already high in the sky. The moment had arrived when the younger girls were to perform a dance. The adult women, sitting in a circle, chanted a sweet, tender song, its rhythm set to the clapping of their hands. The girls took their places around the fire and began to dance.

I had eyes for no one but Naipuni, the most beautiful of all with her white shell bracelets jingling on her wrists and slim ankles. Swaying her hips and arms, she moved with the grace of a young bird on its first flight, still chaste yet already fully aware of being a woman. Her face passed in and out of the luminous circle cast by the flames, disappearing into the shadows then reappearing, caressed by gleams that lit up her cheeks and brow.

At the end of the performance I went up to her, breathless as she was, and asked her to follow me away from the crackling of fires, the singing and people's jabbering. On the shore of the sea, her breathing by then quiet, I took her hand and all in a rush asked her if she would become my wife. Slowly she drew her hand back, raising her dark eyes to me. Then she smiled. The wind which spoke of distance, the white foam of the sea and all the stars in the sky were in that smile. She did not say a word, but from the passionate look in her eyes I understood that she returned my love.

We encountered no difficulties with our respective parents, who on the contrary accepted our decision with pleasure. Fervent, hard-working days followed. When two young people decide to marry the entire village participates in the building of the hut, an elongated structure with dry walls covered with grass and twigs and a solid foundation of dressed stone. I, who had already become a fairly good craftsman, set to work decorating the stone seats and interior surfaces with elegant designs. For Naipuni I carved a seat that was so exquisite it looked like a throne.

How vast my island seemed at that time and how promising the ocean where I swam with Naipuni! When we wanted to be alone, we would go to our favourite little white-sand beach at Ovahe, adjacent to the bay of 
Anakena and almost an extension of it. The universe at that time was not a boundless, silent void but a welcoming place in which to dwell, full of meaningful voices. The sonorous wind, the gasping surf, the beating of the wings of a bird in skimming flight were a murmur of the present and a sweet portent of the future that lay before us.

For a long time we would lie stretched out in the sun, side by side, in perfect silence. Sometimes I would lift Naipuni, rearing and laughing, in my arms and carry her with me into those ocean waters that were always somewhat cold. We would frolic around, light-hearted as in the days of our childhood, and I would encircle her waist, submerging her all the way, and then lightly raise her up against the sky. She came up out of the water with her eyes closed and her head tilted back, her long black hair streaming sleek and wet over her shoulders, her brown skin, veiled with a thousand droplets, glistening like the pearly lining of a seashell. She would pretend to show displeasure.

Nothing had existed before us. 